\title{
Kreowanie marek regionów za granicą przez różne grupy interesariuszy na przykładzie wybranych polskich województw
}

\section{Katarzyna Janiszewska}

\begin{abstract}
STRESZCZENIE
Celem artykułu jest ukazanie działań oraz sposobów i zakresu zaangażowania różnego rodzaju interesariuszy w proces kształtowania marki regionu za granicą. W tym celu przeprowadzono pół ustrukturyzowane wywiady indywidualne $\mathrm{z}$ jednym pracownikiem każdego z wybranych pięciu biur regionalnych w Brukseli. Analizie poddano istotę i motywy kształtowania marki regionu, postrzeganie roli biur regionalnych oraz sposób zaangażowania grup interesariuszy w proces. Wyniki wykazały, że wszystkie analizowane województwa widzą potrzebę posiadania silnej międzynarodowej marki. Jest to możliwe po uprzednim zidentyfikowaniu i zbudowaniu tożsamość regionu. W procesie budowania marki zaangażowane powinny być wszystkie grupy interesariuszy. Ze względu na ograniczony czas badania i brak zgody niektórych regionów na udział w badaniu, rekomenduje się uwzględnienie w dalszych badaniach pozostałych polskich województw, a także uwzględnienie pomiarów i skuteczności prowadzonych działań z zakresu brandingu.
\end{abstract}

\section{Wprowadzenie}

Marka miejsca umożliwia regionom ich dalszy rozwój i budowanie przewag konkurencyjnych. Odgrywa istotną rolę przy wyborze miejsca do inwestowania lub zamieszkania, kształtuje także lojalność i przywiązanie jego obecnych mieszkańców. Jest też elementem porządkującym i upraszczającym napływające do świadomości jednostki informacje w logiczną całość, pozwalającym często oddziaływać na wytworzony w umysłach odbiorców wizerunek [Balkiewicz-Żerek i Dudek-Mańkowska 2015, s. 14].

Tak postrzegana marka miejsca jest wiodącym narzędziem marketingowym jednostek samorządu terytorialnego. Osiągnięcie rozpoznawalnej i silnej marki regionu na arenie międzynarodowej jest możliwe tylko przy nieustannym jej kształtowaniu i dostosowywaniu do panujących warunków rynkowych. Władze samorządowe nie są obecnie zdolne, żeby uzyskać taki efekt samodzielnie [Dropek 2014, s. 36-37]. W artykule postanowiono zatem zidentyfikować grupy interesariuszy, obecnych w procesie kreowania marki za granica, w wybranych polskich województwach. Ze względu na ograniczenia badania, wnioski oparto na wywiadach przeprowadzonych wśród pięciu polskich województw: mazowieckiego, lubuskiego, dolnośląskiego, świętokrzyskiego i warmińsko-mazurskiego.

Celem badania było poznanie motywów podejmowania działań z zakresu brandingu przez przedstawicieli biur regionalnych polskich województw w Brukseli, zidentyfikowanie ich roli oraz zaangażowania w kształtowanie marki regionów za granicą oraz określenie grup interesariuszy zaangażowanych $\mathrm{w}$ ten proces. 


\section{Pojęcie interesariuszy}

Pojęcie „interesariusz” po raz pierwszy użyte zostało w 1963 r. w dokumencie Stanford Research Institute [Freeman 2010, s. 31]. Zyskało ono na popularności w latach 80. XX wieku, dzięki teorii interesariuszy R.E. Freemana. Według Freemana interesariusze, to podmioty - osoby, społeczności, instytucje, organizacje, urzędy, które mogą wpływać na organizację i/lub pozostają pod wpływem jej działalności [Freeman 1984, s. 48].

Wieloletnie badania nad zagadnieniem interesariuszy, zaowocowały próbami kategoryzacji ich grup. Najbardziej intuicyjnie stosowaną w literaturze klasyfikacją jest ta, dzieląca interesariuszy na wewnętrznych - wchodzących w skład organizacji i zewnętrznych, którzy, działając w otoczeniu organizacji, wywierają na nią pewien wpływ. Do interesariuszy wewnętrznych zalicza się: pracowników, udziałowców, rady nadzorcze, właścicieli. Do zewnętrznych zaś: klientów, dostawców, konkurentów, władze państwowe, instytucje finansowe, media, związki zawodowe, społeczności lokalne [Łudzińska i Zdziarski 2013, s. 41-49]. Podział ten, choć prawidłowy, nie do końca odnosi się do regionu jako organizacji. W. Rudolf [2011, s. 252-253] sugeruje, aby interesariuszy regionu, dzielić na: partnerów wewnętrznych, partnerów w regionie, partnerów w kraju oraz partnerów za granicą. Partnerzy wewnętrzni to pracownicy urzędów marszałkowskich i jednostek podległych. Partnerzy w regionie to organizacje, które funkcjonują na terenie województwa i posiadają podobne cele do samorządu województwa. Zaliczyć można do nich: jednostki samorządu terytorialnego niższego szczebla z terenu województwa oraz tworzone przez nie związki, wojewodę - jako przedstawiciela rządu w województwie, wszelkie samorządy gospodarcze, samorządy zawodowe, organizacje pozarządowe, uczelnie wyższe, jednostki naukowo-badawcze, przedsiębiorstwa. Partnerzy w kraju to organizacje, które funkcjonują na terenie Polski i mają bezpośredni wpływ na dany region, ale swoją siedzibę mają poza tym regionem. Do grupy tej zaliczono: administrację innych polskich województw, krajowe związki i ugrupowania współpracy województw, administrację centralną. Ostatnią grupą interesariuszy są partnerzy za granicą. Uważa się za nich organizacje, które mają swoją siedzibę poza terytorium Polski, ale jednocześnie współpracują z samorządem regionu. Dzięki relacjom z tymi organizacjami, samorząd województwa może lepiej realizować zakładane cele i wzmacniać pozycję międzynarodową. Są to: Komisja Europejska, organizacje międzynarodowe, administracja regionów innych państw [Rudolf 2011, s. 249]. Autor zaznacza, że w przypadku samorządu terytorialnego „interesariuszem jest ten, kto posiada podstawe prawna do żądania, wymagania, rozliczania" [Rudolf 2011, s. 248], a więc interesariuszem regionu będą wszyscy jego mieszkańcy.

Analizując relacje, jakie mogą zachodzić pomiędzy interesariuszami a organizacja A. Paliwoda-Matiolańska [2005, s. 241] proponuje podział na: interesariuszy wewnętrznych - współtworzących organizację swoją praca, wiedza, kompetencjami i kapitałem, bez których organizacja nie jest w stanie funkcjonować. Drugą grupą są interesariusze kontraktowi - związani z działalnością rynkową organizacji. Zalicza się do nich klientów (w przypadku regionu - mieszkańców), kooperantów, dostawców, instytucje finansowe, media. Ostatnią grupę stanowią różne wspólnoty interesu - czyli wszystkie instytucje społeczne i rządowe, 
społeczność lokalna. Na podstawie tego podziału, można przyjąć, że mieszkańcy regionu będą stanowić zarówno interesariuszy kontraktowych (klientów) jak i wspólnotę interesu (społeczność lokalna).

Freeman [1984] we wspomnianej wcześniej teorii interesariuszy, zakłada, że powodzenie wszelkich przedsięwzięć organizacji jest możliwe, tylko przy równorzędnym uwzględnianiu interesów wszystkich interesariuszy. Ponadto organizacja, podczas tworzenia swojej strategii powinna uwzględniać ich oczekiwania i przez to kształtować swoje dalsze działania. W późniejszych pracach Freeman zakłada wręcz, że zgodnie z teorią interesariuszy przedsiębiorstwo „powinno" być zarządzane dla dobra interesariuszy, a jego menedżerowie "musza" reprezentować interesy wszystkich ich grup. Wygłaszał także pogląd, że każda grupa interesariuszy "ma prawo do bycia traktowana jako cel sam w sobie, a nie tylko jako środek do osiagania jakiegoś celu" [Evan i Freeman 1997, s. 187]. Obecnie coraz częściej w literaturze pojawia się zagadnienie marketingu interesariuszy, wpisujące się w koncepcję społecznej odpowiedzialności przedsiębiorstwa (CSR) [Rudolf 2014, s. 174]. Marketing interesariuszy uwzględnia interesy wszystkich interesariuszy w planowaniu, wdrażaniu i ocenie strategii marketingowej, uświadamia organizacji wpływ decyzji marketingowych na interesariuszy i otoczenie organizacji oraz bada związki istniejące między nimi. Takie podejście skutkuje przekonaniem, że interesariusze wspólnie tworzą wartość z organizacją i dla organizacji [Rudolf 2014, s. 177].

\section{Interesariusze a kreowanie marki regionu}

Po odpowiednim zidentyfikowaniu rodzajów interesariuszy, organizacja, a w tym przypadku region, może zająć się kształtowaniem relacji z tymi podmiotami. Taka analiza może doprowadzić do ustalenia hierarchii ważności grup interesów organizacji i określenia potencjalnych narzędzi wpływania na nie [Anders-Morawska i Rudolf 2015, s. 104]. Celem budowania relacji z różnymi podmiotami są: tworzenie pozytywnego wizerunku organizacji, relacje inwestorskie, relacje ze społecznością lokalną, marketing wewnętrzny i komunikacja zewnętrzna i wewnętrzna [Marcinkowska 2011, s. 47]. Te relacje wchodzą w skład marki regionu.

Marka, zgodnie z zaproponowaną przez American Marketing Association definicja, to: „nazwa, termin, symbol, wzór lub ich kombinacja, stworzona celem identyfikacji dóbr lub usług sprzedawcy lub ich grupy i wyróżnienia ich spośród konkurencji" [Kotler 1994, s. 410], która wiąże się z pewnymi skojarzeniami i doświadczeniami. Jednocześnie podkreśla się, że pojęcie marki nie dotyczy wyłącznie dóbr i usług, ale także organizacji, miejsc, osób lub koncepcji [Kotler i Lee 2008]. Marka regionu to spójna, łatwo identyfikowalna i oferującą określone wartości koncepcja danego regionu [Zdon-Korzeniowska 2012, s. 132]. Na markę miejsca składa się zestaw wartości, idei, cech, dziedzictwa historycznego, kultury, obrazów, słów, które wywołują u odbiorcy pozytywne emocje i określone skojarzenia z regionem [Koźlak 2008, s. 9]. W odniesieniu do miejsc, regionów i jednostek terytorialnych używa się obecnie coraz częściej pojęcia marki terytorialnej. Konstrukt ten łączy w sobie elementy materialne, takie jak: infrastruktura techniczna, architektura, zagospodarowanie turystyczne oraz aspekty nie- 
uchwytne, czyli wartości i przekonania [Korczyńska 2006, s. 4]. Niezmiennie jednak kluczowymi komponentami marki miejsca, czy też marki terytorialnej, jest tożsamość - zbiór cech miejsca, przez pryzmat których chce być ono postrzegane przez otoczenie oraz wizerunek, który tworzy się w wyniku odbioru tożsamości przez różne grupy interesariuszy. Kształtowanie marki miejsc, inaczej branding, jest procesem długotrwałym, mającym na celu zbudowanie pewnego wizerunku miejsca i późniejsze zarządzanie nim [Anholt 2007, s. 4]. Jest to również proces dialogu między grupami interesariuszy nad znaczeniem marki [Hatch i Schulz 2008, s. 32]. Interesariusze są jednocześnie odbiorcami marki regionu, a więc i tożsamości, w umysłach których powstaje pewien wizerunek miejsca oraz kreatorami i uczestnikami procesu tworzenia marki miejsca. Powodzenie kreowania marki regionu zależy od zaangażowania wszystkich grup interesariuszy w ten proces. Decydujący wpływ mają na niego mieszkańcy. Koncepcja, która koncentruje się na obywatelach, jako interesariuszach, to tzw. public governance (współrządzenie publiczne) [Izdebski 2007, s. 16]. W ramach analizy roli interesariuszy, prowadzonej podczas kształtowania marki regionu, najistotniejsze jest rozpoznanie subiektywnie postrzeganej wartości dodanej, która wyróżnia dane miejsce [Florek i Janiszewska 2015, s. 52] oraz aktywne włączenie w proces kształtowania marki regionu wszystkich grup interesariuszy, ze szczególnym uwzględnieniem jego mieszkańców. Skutkiem tych działań powinna być spójna wewnętrznie, rozpoznawalna i silna marka regionu w kraju i za granicą [Kavaratzis 2012, s. 9].

\section{Interesariusze a kształtowanie marki regionu za granicą - badania empiryczne}

Celami zrealizowanego badania były przede wszystkim: poznanie sposobu definiowania działań brandingowych przez przedstawicieli polskich województw w biurach regionalnych w Brukseli, poznanie celów i rodzajów działań, prowadzonych przez przedstawicieli biur regionalnych w zakresie kształtowania marki regionu za granicą oraz identyfikacja grup interesariuszy i ich zaangażowania w proces kształtowania marki regionu za granicą. Badanie miało charakter eksploracyjny, jakościowy. O udział w badaniu poproszono pracowników wszystkich 16 biur przedstawicielskich polskich województw. Zgodę na udział uzyskano od przedstawicieli biur województw: dolnośląskiego, mazowieckiego, lubuskiego, świętokrzyskiego i warmińsko-mazurskiego. Ze względu na brak zgody respondentów na nagrywanie ich wypowiedzi lub ich części, podczas wywiadów posługiwano się scenariuszem, a odpowiedzi notowano. Całość materiałów została przekazana do autoryzacji badanym.

Przed badaniem właściwym, w dwóch biurach przedstawicielskich odbyło się badanie pilotażowe. Weryfikowało ono sposób sformułowania pytań oraz zasadność ich zadawania. Pilotaż wykazał, że pytania obejmują zbyt szeroki zakres tematyczny, część z nich nie powinna być adresowana do przedstawicieli biur, a użyte specjalistyczne słownictwo marketingowe powinno być zastąpione bardziej przystępnym językiem. Na tej podstawie zmodyfikowano scenariusz wywiadu indywidualnego. Znalazło się w nim 7 pytań otwartych oraz 2 pytania zamknięte. Badanie zostało przeprowadzone między 1 sierpnia a 15 września 2016 roku w Brukseli i miało formę pół ustrukturyzowanych wywiadów indywidualnych, 


\section{Tabela 1. Rozumienie terminu kształtowania marki regionu przez ankietowanych}

\begin{tabular}{|c|c|}
\hline \multicolumn{2}{|r|}{ Pytanie: Co to jest kształtowanie marki regionu? } \\
\hline $\begin{array}{l}\text { województwo } \\
\text { mazowieckie }\end{array}$ & $\begin{array}{l}\text { "(...) wszystkie działania, mające na celu zbudowanie w umysłach odbiorców pew- } \\
\text { nego wizerunku”; "powinno to być skojarzenie z logo, logotypem, piktogramami } \\
\text { czy hasłem, ale także kojarzenie z pewnymi podmiotami, np. z sektora spożywczego } \\
\text { z danego regionu (...)" }\end{array}$ \\
\hline $\begin{array}{l}\text { województwo } \\
\text { dolnośląskie }\end{array}$ & $\begin{array}{l}\text { "(...) budowanie wizerunku, który wyraża się w oddziaływaniu na świadomość od- } \\
\text { biorców oraz tworzenie pozytywnych skojarzeń, w oparciu o mocne strony regionu } \\
\text { (...)" }\end{array}$ \\
\hline $\begin{array}{l}\text { województwo } \\
\text { lubuskie }\end{array}$ & $\begin{array}{l}\text { "(...) ogół działań prowadzonych przez region, całość podejmowanych aktywności, } \\
\text { postawa regionu. To także percepcja ludzi, którzy posiadaja pewne osobiste doświad- } \\
\text { czenia (...)" }\end{array}$ \\
\hline $\begin{array}{l}\text { województwo } \\
\text { świętokrzyskie }\end{array}$ & 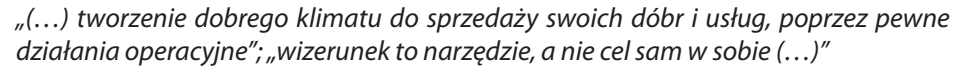 \\
\hline $\begin{array}{l}\text { województwo } \\
\text { warmińsko-mazurskie }\end{array}$ & $\begin{array}{l}\text { "(...) proces opracowania idei przewodniej: sloganu, logo oraz identyfikacji wizualnej } \\
\text { (...)" }\end{array}$ \\
\hline
\end{tabular}

Źródło: opracowanie własne

które trwały po 45-60 min. W każdym biurze regionalnym województw, które zgodziły się na udział w badaniu, tj.: mazowieckim, warmińsko-mazurskim, lubuskim, dolnośląskim, świętokrzyskim, przeprowadzono wywiad z jednym pracownikiem. Wynikało to z ograniczeń personalnych tych biur, gdzie w wielu przypadkach pracuje jedna osoba. Zarówno pilotaż jak i badanie właściwie zostało przeprowadzone bezpośrednio przez autorkę.

Badanie rozpoczęto od pytania o sposób rozumienia terminu „kształtowania marki regionu", którego wybrane wyniki przedstawia tabela 1.

Respondenci udzielili odpowiedzi o zbliżonym znaczeniu. Jedynie przedstawiciel województwa warmińsko-mazurskiego, zawężał ten termin do tworzenia elementów identyfikacji regionu. Odpowiedzi stały się punktem wyjścia do kontynuowania rozważań nad intencjami i motywami podejmowanych działań brandingowych. Wskazywały one na zróżnicowane pola zainteresowania województw oraz przykładowe działania i możliwości biur przedstawicielskich w zakresie kształtowania marki regionu (tabela 2).

Przedstawiciele biur regionalnych jednoznacznie wskazuja, że ich działalność i wszystkie podejmowane inicjatywy rzutują na wizerunek regionu. Pozytywny wizerunek zaś ma na celu zwiększenie zainteresowania regionem, głównie w aspekcie gospodarczym.

Następnie skupiono się na identyfikacji: grup odbiorców działań brandingowych, grup interesariuszy uczestniczących w procesie kształtowania marki oraz grup potencjalnych interesariuszy. Dzięki pytaniu: „Kto jest odbiorcą - czyli „konsumentem” wszelkich działań z zakresu kształtowania marki (wizerunku) regionu? Na kim skupiają się działa- 


\section{Tabela 2. Cele działań brandingowych prowadzonych przez biura regionalne w Brukseli}

\begin{tabular}{|l|l|}
\hline \multicolumn{2}{|c|}{ Pytanie: Co chce osiągnąć region poprzez takie działania (czyli z zakresu kształtowania marki)? } \\
Jaki jest ich cel?
\end{tabular}

Źródło: opracowanie własne

nia? Na jakiej grupie osób?" - uzyskano informacje, iż podstawowymi odbiorcami działań biur regionalnych są instytucje unijne: Komitet Regionów, Komisja Europejska, Stałe Przedstawicielstwo RP przy UE, Ambasada RP przy Królestwie Belgii, WPHI. Ze względu na specyfikę działania Biura Przedstawicielskiego Województwa Lubuskiego, odbiorcą jest głównie strona polska tj. Urząd Marszałkowski Województwa Lubuskiego, jednostki badawcze z lubuskiego zaangażowane w Program Horyzont 2020, parki przemysłowo-technologiczne, uniwersytety i uczelnie wyższe, jednostki rozwoju gospodarczego, urzędy i gminy z terenu województwa lubuskiego. Pozostałymi grupami odbiorców wskazanymi przez respondentów były: przedsiębiorstwa belgijskie i organizacje ich zrzeszające, mieszkańcy, sieci tematyczne i stowarzyszenia związane z administracją unijną, regiony partnerskie, polonia belgijska. Następnie zapytano: „Jakie osoby, grupy są zaangażowane w kreowanie marki regionu? Kto uczestniczy w tym procesie?" Jednogłośnie wskazano swych zwierzchników, czyli Marszałków Województw oraz Urzędy Marszałkowskie. Jednocześnie, jak wynikało z komentarzy, polskie regiony zdają sobie sprawę, że działając razem, mogą osiągnąć więcej, dlatego też na drugim miejscu stawiają pozostałe polskie biura w Brukseli. Kolejną wymienioną grupą interesariuszy zaangażowanych w kształtowanie marki regionu są przedsiębiorcy pochodzący z danego regionu. Za istotne uznawane 


\section{Tabela 3. Rodzaje podejmowanych działań związanych z kreowaniem międzynarodowej marki regionu}

\begin{tabular}{|l|c|}
\hline \multicolumn{1}{|c|}{ Nazwa działania } & $\begin{array}{c}\text { Liczba } \\
\text { wskazań }\end{array}$ \\
\hline $\begin{array}{l}\text { Członkostwo województwa lub jego władz w międzynarodowych organizacjach, stowarzysze- } \\
\text { niach, sieciach współpracy }\end{array}$ & 5 \\
\hline Kontakty z partnerskimi regionami/miastami & 5 \\
\hline Wyjazdy studyjne za granicę & 3 \\
\hline Wymiana urzędników, praktykantów z zagranicą & 4 \\
\hline Wykorzystywanie „dobrych praktyk" z zagranicy & 5 \\
\hline Współorganizowanie międzynarodowych imprez kulturalnych, sportowych itp. & 5 \\
\hline Udział w międzynarodowych konferencjach & 5 \\
\hline $\begin{array}{l}\text { Udział we wspólnych projektach naukowych z zagranicznymi jednostkami samorządu tery- } \\
\text { torialnego }\end{array}$ & 1 \\
\hline
\end{tabular}

Źródło: opracowanie własne

są także: regiony partnerskie, z którymi podpisane są umowy bilateralne, partnerzy z sieci współpracy, mieszkańcy regionu, europosłowie, Stałe Przedstawicielstwo i Ambasada RP oraz różnego rodzaju instytucje kultury z terenu analizowanych regionów lub tych, działających na terenie Belgii.

Pytanie o potencjalnych interesariuszy („,Czy uważa Pani, że ktoś, kto obecnie nie bierze udziału w działaniach brandingowych, powinien się w nie włączyć?”), poskutkowało zgodną odpowiedzą wszystkich regionów, że takie grono zawsze może być poszerzone. Istnieją jednak ograniczenia finansowe i osobowe do podejmowania takich działań. Zdaniem niektórych badanych, nie zawsze zaangażowanie nowych podmiotów podnosi skuteczność działań. Co więcej, przedstawiciele województw: dolnośląskiego, lubuskiego i warmińsko-mazurskiego uważaja, że wszystkie możliwe podmioty są już zaangażowane w cały proces. Mazowsze chciałoby poszerzyć współpracę o jednostki naukowe, które zdaniem respondenta, rzadko kojarzone są z regionem. Przedstawiciel województwa świętokrzyskiego uważa natomiast, że zaangażować powinny się stowarzyszenia i organizacje studenckie.

Kolejnym etapem było zaprezentowanie badanym listy działań, które kojarzone są ściśle z kształtowaniem marki oraz orientacją międzynarodową regionów (tabela 3). Poproszono o wskazanie wszystkich podejmowanych przez nich i ich region działań. W przypadku odpowiedzi twierdzącej, konieczne było rozwinięcie i uszczegółowienie, w jakim stopniu i poprzez jakie działania są te inicjatywy realizowane. Nie narzucono ograniczeń dotyczących liczby wskazań poszczególnych aktywności. 
Wszystkie badane województwa należą do międzynarodowych organizacji i nawiązują współpracę z regionami partnerskimi. Jednocześnie w swojej działalności wszystkie regiony korzystają z dobrych praktyk, organizują różnego rodzaju wydarzenia o charakterze międzynarodowym i uczestniczą w konferencjach międzynarodowych o różnorodnej tematyce. Tylko jeden region uczestniczy we wspólnych projektach naukowych z zagranicznymi regionami.

Ograniczony zakres odpowiedzi w tabeli uzupełniono pytaniem: „Czy oprócz wymienionych, są jakieś inne działania podejmowane na forach międzynarodowych? Na jakiej tematyce się skupiają?" Mazowsze wskazało działania typu public relations, a województwo świętokrzyskie organizuje spotkania application-to-business oraz business-to-business.

Mając na względzie znaczną aktywność biur przedstawicielskich polskich regionów w Brukseli, zapytano badanych: „Czy prowadzą Państwo pomiary skuteczności działań brandingowych? Czy są jakieś mierniki, wskaźniki?" Odpowiedzi wykazały, że żadne z Biur nie prowadzi własnych pomiarów skuteczności. Zaznaczono także, że jeśli takie pomiary są prowadzone, to biura przedstawicielskie nie dysponują informacjami na ten temat.

Kończąc rozmowę, zadano pytanie: „Jakie są według Pani/a najważniejsze aspekty w osiągnięciu sukcesu w kreowaniu pozytywnego wizerunku regionu?" Respondentom przedstawiono czynniki sukcesu w marketingu miejsc za S. Rainisto [2003, s. 253-254], którymi są: grupa planowania, wizja i analiza strategiczna, tożsamość i wizerunek miejsca, partnerstwo publiczno-prywatne, jedność polityczna, konkurencyjność regionu na rynku międzynarodowym i rozwój lokalny, procesowe zbiegi okoliczności, przywództwo. Za autorem przytoczono definicję i rozumienie poszczególnych czynników. Na tej podstawie badani mieli za zadanie wybrać trzy, ich zdaniem, najważniejsze aspekty.

Mazowsze za kluczowe czynniki uznało: tożsamość i wizerunek regionu, posiadanie spójnej i wiarygodnej wizji/strategii oraz jedność polityczna, rozumianą jako kontynuację działań przez kolejne władze. Dolny Śląsk wskazał za najistotniejsze: tożsamość i wizerunek, wizję i analizę strategiczną oraz grupę planowania. Lubuskie uważa, że o sukcesie decydują: grupa planowania i jej zdolności organizacyjne, tożsamość i wizerunek miejsca oraz wizja i analiza strategiczna. Świętokrzyskie jako najważniejsze czynniki wskazuje: tożsamość i wizerunek - „znalezienie unikalności regionu, która stanie sie przewaga konkurencyjna na arenie międzynarodowej”, grupę planowania - „kwalifikacje, umiejętności miękkie, zaangażowanie, elastyczność pracowników" oraz konkurencyjność regionu na rynku międzynarodowym i rozwój lokalny. Warmińsko-mazurskie wskazało takie trzy czynniki jak: grupa planowania, gdyż "to kwalifikacje osób zatrudnionych i odpowiedzialnych maja wptyw na finalny efekt”, jedność polityczna oraz tożsamość i wizerunek regionu, którego „atrakcyjność skutkuje korzyściami finansowymi dla regionu".

Najczęściej powtarzającym się czynnikiem sukcesu były: tożsamość i wizerunek, o których wspomniały wszystkie regiony. Nie mniej ważne są grupa planowania oraz wizja i analiza strategiczna, które wskazały 3 z 5 regionów. Dwa regiony uważają że o sukcesie decyduje jedność polityczna. Świętokrzyskie jako jedyne uznało za kluczową konkurencyjność regionu na rynku międzynarodowym i rozwój lokalny. 


\section{Wnioski}

Na podstawie przeprowadzonych badań można sformułować wniosek, że administracja polskich regionów jest $\mathrm{w}$ wysokim stopniu zaznajomiona $\mathrm{z}$ koncepcją brandingu i świadoma jego potrzeby.

Wszystkie z badanych województw dostrzegają potrzebę posiadania silnej międzynarodowej marki, która, w ich przekonaniu, prowadzi do zwiększonego zainteresowania gospodarczego regionem i w konsekwencji poprawy życia jego mieszkańców. Kreowanie i posiadanie silnej marki nie zależy jednak wyłącznie od dobrej woli jego władz czy pracowników urzędów, ale od zaangażowania w ten proces wszystkich grup interesariuszy. Regiony mają świadomość ich znaczenia dla kształtowania marki, lecz zróżnicowane zaangażowanie grup interesariuszy w kształtowanie marki regionu zależy od profilu i specjalizacji danego województwa i powinno być rozpatrywane indywidualnie. Trudno także na razie mówić o zaangażowaniu mieszkańców danego województwa w kształtowanie marki regionu za granica, ich rola w tym aspekcie jest znikoma.

Czynniki sprzyjające kształtowaniu silnej marki regionu, na podstawie wypowiedzi badanych, ale także literatury przedmiotu, były zgodne z wynikami uzyskanymi we wcześniejszych badaniach. S. K. Rainisto [2003] uważa, że "grupa planowania, wizja i analiza strategiczna, tożsamość miejsca i wizerunek, partnerstwa publiczno-prywatne i przywództwo, stanowia podstawowy element budowy marki miejsca w praktyce marketingowej".

Na biurach przedstawicielskich polskich województw w Brukseli spoczywa więc obowiązek kreowania wizerunku swojego regionu za granicą. Na dbałość o ten wizerunek składać się muszą nie tylko działania "twarde”, ale także „miękkie”- dynamizm, otwartość, chęć działania. Tylko w ten w sposób można zachęcić innych interesariuszy do włączenia się w proces kreowania marki regionu, a także przekonać władze regionu i jego mieszkańców o relatywnych korzyściach z podejmowania takich działań.

\section{Bibliografia}

Anders-Morawska J., Rudolf W., 2015, Orientacja rynkowa we wspótrządzeniu miastem, Wydawnictwo Uniwersytetu Łódzkiego, Łódź.

Anholt S., 2007, Competitive identity. The New Brand Management for Nations, Cities and Regions, Macmillan, Nowy Jork.

Balkiewicz-Żerek A., Dudek-Mańkowska S., 2015, Siła marki miejsca, „Marketing i Rynek”, 6, s. 14-23. 
Dropek K., 2014, Działania samorzadu terytorialnego wspierające przedsiębiorczość w gminach województwa wielkopolskiego, „Studia Oeconomica Posnaniensia”, 2, 2, s. 36-54.

Evan W.M., Freeman R.E., 1997, Spótka i osoby żywotnie zainteresowane. Kapitalizm, Wydawnictwo „W drodze”, Poznań.

Florek M., Janiszewska K., 2015, Marka i jej tożsamość jako źródło wartości dodanej obszaru metropolitalnego, "Studia Oeconomica Posnaniensia”, 3, 8, s. 49-66.

Freeman R.E., 1984, Strategic Management. A Stakeholder Approach, Cambridge University Press, Cambridge.

Godlewska-Majkowska H. (red.), 2016, Atrakcyjność inwestycyjna regionów 2016 - raport zbiorczy, Warszawa.

Hatch M.J., Schulz M., 2008, Taking Brand Initiative: how companies align strategy, culture and identity through Corporate Branding, San Francisco.

Izdebski H., 2007, Od administracji publicznej do public governance, "Zarządzanie Publiczne”, 1, s. 9-22.

Kavaratzis M., 2012, From "necessary evil" to necessity: stakeholders 'involvement in place branding, "Journal of Place Management and Development", 5, 1, s. 7-19.

Kotler Ph., 1994, Marketing, Gebethner i Ska, Warszawa.

Kotler Ph., Lee N., 2008, Marketing w sektorze publicznym. Mapa drogowa wyższej efektowności, Warszawa.

Korczyńska M., 2006, Marka miasta, „Marketing i Rynek”, 12, s. 2-10.

Koźlak A., 2008, Wpływ wizerunku marki regionu na jego konkurencyjność, „Zeszyty Naukowe Uniwersytetu Szczecińskiego: Ekonomiczne Problemy Usług", 26, s. 5-14.

Łudzińska K., Zdziarski M., 2013, Interesariusze w opinii prezesów zarządów polskich przedsiębiorstw, Warszawa.

Marcinkowska M., 2011, Tworzenie wartości przedsiębiorstwa dla interesariuszy, "Zeszyty Naukowe Uniwersytetu Szczecińskiego: Finanse, Rynki Finansowe, Ubezpieczenia”, 37, S. $42-57$.

Olszewska J., 2000, Wizerunek jako narzędzie tworzenia przewagi strategicznej gminy, „Marketing i Rynek", 11, s. 24-37.

Paliwoda-Matiolańska A., 2005, Teoria interesariuszy w procesie zarzadzania współczesnym przedsiębiorstwem, [w:] H. Burdulak i T. Gołębiowski (red.), Wspólna Europa. Zrównoważony rozwój przedsiębiorstwa a relacje z interesariuszami, SGH, Warszawa.

Rainisto S.K., 2003, Success Factors of Place Marketing: a Study of Place Marketing Practices in Northern Europe and the United States, Espoo. 
Rudolf W., 2011, Samorzad regionu i jego partnerzy - typologia relacji w marketingu regionu, [w:] Marketing Przyszłości. Trendy. Strategie. Instrumenty. Wybrane Aspekty Marketingu Terytorialnego, „Zeszyty Naukowe Uniwersytetu Szczecińskiego, 663, s. 243-256.

Rudolf W., 2014, Marketing interesariuszy - nowy wymiar marketingu relacji, „Marketing i Rynek", 8, s. 174-179.

Zdon-Korzeniowska M., 2012, Budowa marki regionalnej na wybranych przykładach województw Polski, „Prace Komisji Geografii Przemysłu”, 19, s. 130-141.

The creation of regions' brand abroad by different groups of stakeholders on the example of selected polish voivodships

\section{ABSTRACT}

The aim of this article is to illustrate measures as well as means and range of involvement taken by different types of stakeholders in the process of region's branding abroad. For this purpose semi-structured individual interviews with one employee from each of five selected regional offices have been conducted in Brussels. The essence and motives of the region's branding, the role of regional offices and the involvement of stakeholders in the whole process have been analyzed. The results of the analysis indicate that all analyzed voivodships recognize the need to possess a strong, international brand, which can be achieved after identifying and creating region's identity. In the process of branding all groups of stakeholders should be involved. Due to the limited duration of the study and the lack of agreement of some regions to participate in it, it is recommended to consult other Polish voivodships in further studies and to analyze measurements and the effectiveness of performed actions concerning branding.

Katarzyna Janiszewska, doktorantka Kolegium Gospodarki Światowej Szkoły Głównej Handlowej w Warszawie; zajmuje się marketingiem międzynarodowym w jednostkach samorzadu terytorialnego / Master of management and the PhD student at the Warsaw School of Economics; interesed in international marketing in local government unitskontakt/contact: blanka.janiszewska@gmail.com 